\title{
IMPACT OF AIR POLLUTION ON THE OCCURRENCE OF RHYTISMA ACERINIUM “TAR-SPOT" ON MAPLE LEAVES
}

\author{
PIOTR KOSIBA \\ Department of Ecology, Biogeochemistry and Environmental Protection, \\ Institute of Plant Biology, Wroclaw University \\ Kanonia 6/8, 50-328 Wrocław, Poland \\ e-mail: kosibap@biol.uni.wroc.pl
}

(Received: September 4, 2006. Accepted: May 12, 2007)

\begin{abstract}
The aim of the study was, to find out whether the occurrence of Rhytisma acerinium and the variability of numbers of the "tar-spot" fungus on Acer platanoides leaves depend on the degree of environmental pollution. A significant variability was found between sites in relation to contents of chemical elements in soils, leaves and numbers of "tar-spots". The similarity of sites presented in dendrograms classified them as industrial, urban-agglomeration and vehicle-transport areas. The factor and PCA analyses showed that two factors differentiate the soil of the sites in respect of $\mathrm{Fe}, \mathrm{Cu}, \mathrm{Co}, \mathrm{Mo}, \mathrm{Cr}, \mathrm{Ni}, \mathrm{Cd}$ and $\mathrm{N}, \mathrm{S}, \mathrm{Mn}, \mathrm{Pb}$. In case of leaves of A. platanoides populations differentiate them in respect of $\mathrm{N}, \mathrm{S}, \mathrm{Fe}, \mathrm{Pb}, \mathrm{Zn}, \mathrm{Co}, \mathrm{Be}, \mathrm{Cr}, \mathrm{Cd}$ and $\mathrm{Mn}, \mathrm{Cu}, \mathrm{Mo}$. The different air pollutions affect significantly the numbers of "tar-spots" on leaves. Sites with the highest contents of elements do not show "tar-spots", and the factors restricting their occurrence are the high contents, mainly of $\mathrm{N}, \mathrm{S}\left(\mathrm{NO}_{\mathrm{X}}, \mathrm{SO}_{\mathrm{X}}\right)$ and heavy metals. In sites, with the lowest contents of these elements massive infections take place. The occurrence of $R$. acerinium corresponding with the level of site pollution can be used as a tool for evaluation of the degree of environmental pollution.
\end{abstract}

KEY WORDS: Rhytisma acerinium, "tar-spot”, infection, nitrogen, sulphur, heavy metals, bioindication.

\section{INTRODUCTION}

The environmental chemism needs investigations on impact of pollution upon various organisms (Walker et al. 2002; Bell and Treshow 2004). The monitoring of environment became the requirement of the present and is treated as an element of control and prediction of threats (Siwicki 1999; Markert et al. 2003; Poikolainen 2004). These authors consider that it is difficult to say, which of the bioindicators are most effective and mention that every element of the ecosystem can be a valuable informant on degradation and environmental threat. The introduction of new bioindicators enables a more precise determination of toxicity, mechanisms of xenobiotics action, habitat requirements and life strategies of organisms, which ought to be developed, as they are insufficiently known (Hutchinson and Sager 2000; Norden and Appelqvist 2001). According to Market et al. (2003), plants having the indicator or accumulator type of response could potentially be used as "biomonitors", defined as organisms that contain information on quantitative aspects of quality of the environment, and the response of plants can be the answer to concentrations of various elements in soil and aerial deposit (Baker 1981; Baker et al. 2000; Madejón et al. 2004). The numerous home and world literatures for years inform on results of bio- indicator investigations. The objects of bioindication analyses are above all lichens, mosses and also shrubs and trees. But, available information concerning fungi and air pollutants is sparse as compared to lichens and bryophytes (Burton 1986). Since that time, a few authors have discussed fungi as potential bioindicators of air pollution (Fellner 1989; Marx and Shafer 1989). Fellner (1989), Fellner and Pešková (1995) proposed the mycorrhizal fungus Russula mustelina as a potential bioindicator of air pollution and recommended it as a suitable myco-bioindicator in mountain and submountain spruce forests of central Europe. Schaffers and Termorshuizen (1989) obtained strong negative correlations between the number of mycorrhizal fungal species on field stands of Pinus sylvestris and the occurrence of fruit bodies with levels of $\mathrm{NH}_{3}$ and $\mathrm{SO}_{2}$. Fenn et all. (1989) have stated in California the percentage frequencies, and diversity indices were used to measure the effects of $\mathrm{O}_{3}$ and $\mathrm{SO}_{2}$ on leaves colonized by fungi of three tree species: Sequoiadendron giganteum, Quercus kelloggii and Citrus sinensis. Chronic exposure of the trees to pollutants reduced the fungal populations and, to a lesser extent, reduced fungal diversity on the leaves. The most often occurring fungi on maples leaves are $R$. acerinium and $R$. punctatum and are used as indicators of pollution in order to determine $\mathrm{SO}_{2}$ concentrations in the air (Bevan and Gre- 
enhalgh 1976; Vick and Bevan 1976; Greenhalgh and Bevan 1978; Leith and Fowler 1987; Dowding and Richardson 1990; Dowding 1994) and demonstrated the suitability of leafyeasts for assessing air quality in both urban and rural areas. Other studies concentrate on effects of air pollutants on host/pathogen combinations, however these are generally impact assessments associated with economic crop and forest species rather than in the context of air pollution monitoring (Lorenzini et al. 1990; Singh and Bharat, 1990; Tiedemann et al., 1991).

The Rhytisma fungi are parasites occurring on leaves of angiospermous trees. How inform Cheng-Lin and Piepenbring (2005) after Hawksworth et al. (1995); Kirk et al. (2001), that 15 species were recognized, and the species nomenclature is often derived from the name of their host, e.g. $R$. acerinium - Acer spp., $R$ rhododendrii - Rhododendron ssp., $R$. ilicis - Ilex spp., $R$. lonicericola - Lonicera spp., $R$. salicinum - Salix spp. Those fungi find their hosts among various trees and shrubberies, mainly shaded, e.g. Acer spp., Ilex spp., Juglans spp., Liriodendron spp., Lonicera spp., Salix spp., Ulmus spp., and cause one of the most visible, but slight and least harmful diseases. However, heavy infections do not often cause a premature defoliation. According to Szabó (2003) Acer spp. have numerous leaf pathogens, 17 species were identified, and the most frequent one proved to be $R$. acerinium. According to Jones (1925), Duravetz and Morgan-Jones (1971) the early symptoms of the host's leaves infection by $R$. acerinium can be observed in spring. The sources of infection are the black stomata on the host's dropped leaves. After overwintering, on the stomata numerous apothecia are formed, and in them the acrospores. Next, the infection of the upper surface of the host's leaves takes place. Visible are small overcolourings of several millimetres in diameter, rather oval in shape and of light-green or yellow-green color. These small overcolourings grow through the summer to ca. 1-2 cm in diameter and change their color. The center of the overcolouring, the so-called "tar-spot", takes in $R$. accerinium a black pigmentation and is surrounded by a yellowish ring of 1-3 mm width. In the center of the "tarspot", in hollows of the stomata, the microconidal form of the fungus Melasmia acerina develops. In autumn, on the growing yellow and brown leaves, and next on the dropped ones, the stomata get distinctly black without the yellow aureole. The stomata spend the winter on the dropped leaves, and in spring the cycle begins again from the outset. $R$. acerinium is a common fungus with inclination to occur mainly in wet and shaded places. It needs for its development a cool weather, small but frequent rain and a high humidity. It occurs mainly on leaves of shaded trees in communities of Acer platanoides and A. pseudoplatanus. It occurs less often on single trees or trees in double rows, seldom in industrial and urbanized areas (Sutton 1980; Farr et al. 1989; Weber and Webster 2002). We can see in literature, that bioindication studies with $R$. acerinium are few, but investigations on numbers of "tar-spots" in respect of environment pollution are lacking.

In the present paper the hypothesis has been put forward, that the occurrence of $R$. acerinium (Pers.) Fr. and the variability of numbers of the "tar-spots" on A. platanoides L. leaves depend on the degree of environmental pollution. The answer to the hypothesis has been obtained through undertaking investigations concerning:

- The contents of selected elements in Acer platanoides leaves and soil, and the numbers of "tar-spots",

- Determination of of environmental pollution elements that affect the occurrence of the fungus,

- To find out, whether the applied numerical tools are proper for assessing environmental pollution in bioindication studies.

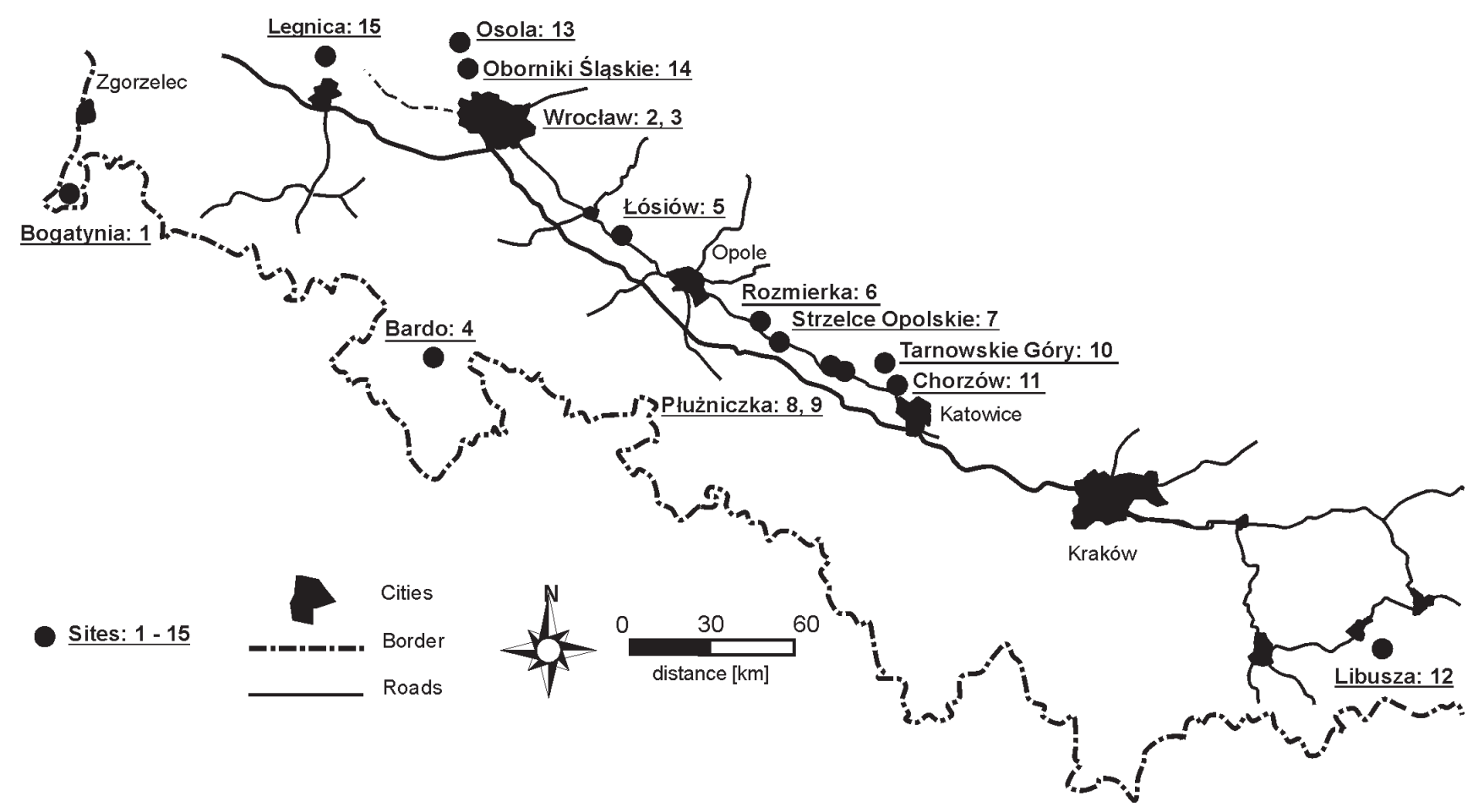

Fig. 1. Localization of the sampling sites of Acer platanoides in the southern part of Poland. 


\section{MATERIAL AND METHODS}

\section{Study area and data collection}

The investigations have been carried out in the southern part of Poland, in the area of Lower, Upper Silesia and Małopolska, in the first decade of July 2006. Established were 15 sites which are located along transect between $50^{\circ} 55^{\prime}$ and $49^{\circ} 41^{\prime} \mathrm{N}$, and $14^{\circ} 59^{\prime}$ and $21^{\circ} 15^{\prime} \mathrm{E}$ (Fig. 1).

The sites have been selected according to their localization, i.e. areas of different degree of industrialization (1 and 15 - Bogatynia and Legnica), urbanization (2, 3 and 10, 11 - Wrocław and Tarnowskie Góry, Chorzów), intensity of traffic (5, 6, 7, 8 and 9 - Łosiów, Rozmierka, Strzelce Opolskie and Płużniczka) and areas beyond direct influence of pollution-emission sources (4, 12, 13, 14 - Bardo, Libusza, Osola, Oborniki Śląskie). Every site was represented by seven area samples of $A$. platanoides including twelve trees in each, occurring in a plant community or in lines (height $12-15 \mathrm{~m}$, trunk circumference 0.90 to 1.3 $\mathrm{m}$ measured at height of $1.80 \mathrm{~m}$ above ground surface). The distance between the samples was ca. 50 to $240 \mathrm{~m}$ and fluctuated between the selected individuals from 15 to 35 $\mathrm{m}$ in community and from 6 to $12 \mathrm{~m}$ in lines. Single growing individuals and those growing at community edges were omitted. From A. platanoides individuals collected were 20 to 37 leaves from various sides of the outer zone of the tree crown. The leaves have been collected from four branches, ca $1 \mathrm{~m}$ long, from height of 2 to $3 \mathrm{~m}$ above ground surface. For assessments of representative branch samples the systematic method has been used. In practice, they were determined through drawing the contour line of the tree crown on the ground surface. Next, by measuring its circumference and dividing it by the number of branches, the constant distance between the points were obtained. The distances between them on a single specimen were constant, in case of lacking branch in determined point, chosen was the closest one. However, the distances betwe- en the branches were variable in the remaining individuals, depending on the size of its crown circumference.

Fresh leaves were segregated and the number of "tarspots" were counted.

The leaves were washed in distilled water and their green parts were separated from parts infected by $R$. acerinium. The chemical analysis was carried out on the green parts of leaves, because "tar-spots" decompose the infected parts of the leave (Cornelissen et al. 2000; Corbin et al. 2003). The isolated green parts of leaves were dried to a constant weight in temperature of $70-90^{\circ} \mathrm{C}$, and next homogenized in an agate mortar and burned in a muffle furnace in temperature of $450^{\circ} \mathrm{C}$ for 8 hours. Leaf samples $(250 \mathrm{mg}$ ) were submerged in $5 \mathrm{ml}$ concentrated $\mathrm{HNO}_{3}$ and then burned in a microwave oven CEM-MARS 5. After dilution by bi-distilled water, the contents of $\mathrm{Cd}, \mathrm{Cr}, \mathrm{Cu}, \mathrm{Fe}, \mathrm{Mn}, \mathrm{Mo}$ and $\mathrm{Zn}$ in the samples were determined by means of the atomic absorption spectrophotometer GBC Scientific Equipment Pty. Ltd. model AVANTA PM, whereas $\mathrm{Be}, \mathrm{Co}, \mathrm{Ni}$ and $\mathrm{Pb}$ were determined by means of the graphite furnace Model GF 3000. After burning the leaf samples in spectrally clean concentrated $\mathrm{H}_{2} \mathrm{SO}_{4}$ in the mineralization apparatus $\mathrm{KB}$ $8 \mathrm{~S}$ Gerhardt, the total content of $\mathrm{N}$ was determined by Kjeldahl's method using the automatic aggregate for distillation WAPODEST 40 Gerhardt. The content of S was determined using the integrated analyzer CNS Carbo Erba NA-1500. The results were expressed in $\mathrm{mg} / \mathrm{kg}$ dry weight of plant.

Soil samples were collected within a radius of 2 to 3 $\mathrm{m}$ from every individual tree, at depth of 10 to $20 \mathrm{~cm}$, at the same time as leaves. After removing rubbish and other remainders, the air-dried samples were homogenized in an agate mortar and sifted through a sieve with plastic network of $1 \mathrm{~mm}$ diameter. The soil samples of $250 \mathrm{mg}$ weight were digested with $5 \mathrm{ml}$ nitrohydrochloric acid in proportion 3:1 and burned. After dilution up to $25 \mathrm{ml}$ with bidistilled water the samples were subject to chemical analy-

TABLE 1. Chemical characteristics of soils from Acer platanoides sites.

\begin{tabular}{|c|c|c|c|c|c|c|c|c|c|c|c|c|c|}
\hline Site number & $\mathrm{N}$ & $S$ & $\mathrm{Fe}$ & $\mathrm{Mn}$ & $\mathrm{Pb}$ & $\mathrm{Zn}$ & $\mathrm{Cu}$ & $\mathrm{Co}$ & Mo & $\mathrm{Be}$ & $\mathrm{Cr}$ & $\mathrm{Ni}$ & $\mathrm{Cd}$ \\
\hline & \multicolumn{13}{|c|}{$\mathrm{mg} / \mathrm{kg}$} \\
\hline 1 & 3605 & 2605 & 3581 & 431 & 34.4 & 404 & 64 & 16.3 & 3.9 & 2.6 & 32.6 & 20.9 & 3.3 \\
\hline 2 & 4238 & 3220 & 2606 & 383 & 55.8 & 219 & 28 & 8.7 & 1.7 & 0.9 & 19.8 & 14.3 & 2.1 \\
\hline 3 & 3186 & 2186 & 1937 & 323 & 42.3 & 187 & 33 & 6.9 & 1.0 & 1.4 & 24.6 & 11.4 & 1.7 \\
\hline 4 & 1317 & 917 & 1520 & 175 & 12.4 & 85 & 12 & 2.2 & 0.2 & 0.1 & 3.6 & 1.7 & 0.1 \\
\hline 5 & 3379 & 2379 & 2167 & 212 & 35.9 & 128 & 11 & 7.7 & 2.4 & 0.6 & 12.2 & 2.0 & 0.5 \\
\hline 6 & 1751 & 751 & 812 & 121 & 12.6 & 71 & 17 & 4.2 & 1.0 & 0.3 & 6.6 & 3.0 & 0.2 \\
\hline 7 & 2011 & 1011 & 1151 & 169 & 27.2 & 169 & 9 & 2.9 & 1.6 & 0.2 & 3.3 & 3.7 & 0.3 \\
\hline 8 & 1736 & 736 & 981 & 113 & 15.7 & 110 & 6 & 3.1 & 0.4 & 0.3 & 1.7 & 2.3 & 0.1 \\
\hline 9 & 1681 & 681 & 1350 & 253 & 12.1 & 77 & 8 & 1.5 & 1.9 & 0.1 & 2.2 & 1.4 & 0.2 \\
\hline 10 & 2730 & 3830 & 1458 & 362 & 16.4 & 257 & 15 & 10.2 & 1.7 & 0.9 & 9.3 & 10.2 & 0.7 \\
\hline 11 & 4846 & 4846 & 3761 & 624 & 84.2 & 664 & 33 & 32.2 & 2.2 & 1.7 & 3.5 & 31.8 & 3.8 \\
\hline 12 & 2436 & 1436 & 695 & 137 & 85.0 & 112 & 11 & 0.9 & 0.3 & 0.1 & 2.1 & 3.0 & 0.2 \\
\hline 13 & 1787 & 987 & 2198 & 156 & 12.4 & 87 & 4 & 3.2 & 0.4 & 0.5 & 1.7 & 1.6 & 0.1 \\
\hline 14 & 1304 & 1304 & 1838 & 284 & 17.4 & 131 & 12 & 4.2 & 0.4 & 0.3 & 2.3 & 1.8 & 0.3 \\
\hline 15 & 3907 & 2807 & 7267 & 504 & 62.4 & 746 & 74 & 45.7 & 6.8 & 1.8 & 63.5 & 45.7 & 6.1 \\
\hline F & 45.6 & 171.5 & 87.4 & 24.7 & 67.1 & 129.7 & 67.2 & 28.1 & 26.8 & 54.1 & 57.9 & 108.4 & 37.4 \\
\hline $\mathrm{F}_{0.05}$ & & & & & & & 1.80 & & & & & & \\
\hline LSD & 216.4 & 79.1 & 134.8 & 78.7 & 18.7 & 57.9 & 12.4 & 9.8 & 0.6 & 0.3 & 6.4 & 4.2 & 0.5 \\
\hline
\end{tabular}


sis of: $\mathrm{Be}, \mathrm{Cd}, \mathrm{Cr}, \mathrm{Co}, \mathrm{Cu}, \mathrm{Fe}, \mathrm{Mg}, \mathrm{Mn}, \mathrm{N}, \mathrm{Ni}, \mathrm{Pb}, \mathrm{S}$, and $\mathrm{Zn}$, using the same methods and measuring devices as in case of A. platanoides leaves. The results were expressed in $\mathrm{mg} / \mathrm{kg}$ air-dried soil mass.

The accuracy of analytical results was verified in relation to reference data GBW 07604 Poplar Leaves. The chemical analysis of $A$. platanoides leaves and soil samples was carried out in three chemical measurement repetitions.

\section{Statistical-mathematical methods}

All the obtained results were subject to statistical-mathematical analysis. For measurements of the analyzed traits calculated were arithmetic means. The goodness of fitting of empirical data to normal distribution was verified by the Shapiro-Wilk's test, which is the preferred and effective test for estimation of traits' normality for a small number of samples (Conti et al. 2005). The variability of examined traits has been determined by means of analysis of variance one-way ANOVA with F test. The variability of mean values was obtained by means of LSD. The similarity of sites has been analyzed using the method of cluster analysis. Applied was the Ward's method of amalgamation, and as measure of similarity the Euclidean distance was accepted. The arrangement of objects at fixed criteria of cluster analysis is presented graphically in form of dendrograms. For analysis of internal relations in sets of quantitative traits the factor analysis and analysis of PCA was used. For separation of common factors of the given sets of traits calculated were the matrix elements of their correlations. Next the factor loadings were determined using the "normalized varimax rotation". By means of the slope plot diagram the number of factors was separated, the value of which is higher than 1. On the basis of that analysis selected were the traits highly correlated with principal components (at load value $>0.70$ ), which explained most of the existing variability. The multidimensional correlations were presented graphically through the projection of variables and cases on surfaces of circles and in coordinate systems.
All calculations and the statistical verification of results were carried out at significance level $\mathrm{p}<0.05$, using the program STATISTICA (StatSoft, Inc. 2005) according to the principles of statistical-mathematical analysis given by Legendre and Legendre (1998), Sokal and Rohlf (2003). The numerical techniques used in ecological investigations, i.e. collecting quantitative information on the object, analysis and interpretation of results and the realization of numerical procedures was based on principles given by Brower et al. (1998).

\section{RESULTS AND DISCUSSION}

\section{ANOVA analysis of soil and leaves chemical properties from examined sites}

The investigated Acer platanoides sites differ significantly in respect of the analyzed elements in soil (Table 1).

This points to the chemically differentiated deposit of air pollution. Basing on localization of sites it is possible to state that sites 1 (Bogatynia) and 15 (Legnica) are under the influence of industrial emissions (coming mainly from the Turoszów Basin and the LGOM), sites 3 (Wrocław), 10 (Tarnowskie Góry) and 11 (Chorzów) by pollution of urban character, and sites 2 (Wrocław), 5 (Łosiów), 6 (Rozmierka), 7 (Strzelce Opolskie) and 8, 9 (Płużniczka) are contaminated mainly by motor-vehicle transport. The remaining sites 4 (Bardo), 12 (Libusza), 13 (Osola) and 14 (Oborniki Śląskie) are locally not directly connected with the mentioned above emission sources, but only with small local ones. It is supposed, that the factor conditioning the differentiation of sites' pollution is the chemism of pollutions, both in quantitative and qualitative respect (KabataPendias 2001). This is also confirmed by investigations of Sawicka-Kapusta et al. (2003) and Salemaa et al. (2004). These authors found, that the quantitative and qualitative composition of dust-gaseous emissions depend on the type of emission sources which condition the environmental

TABLE 2. Chemical characteristics of Acer platanoides leaves from examined sites.

\begin{tabular}{|c|c|c|c|c|c|c|c|c|c|c|c|c|c|}
\hline Site number & $\mathrm{N}$ & $\mathrm{S}$ & $\mathrm{Fe}$ & Mn & $\mathrm{Pb}$ & $\mathrm{Zn}$ & $\mathrm{Cu}$ & Co & Mo & $\mathrm{Be}$ & $\mathrm{Cr}$ & $\mathrm{Ni}$ & $\mathrm{Cd}$ \\
\hline & \multicolumn{13}{|c|}{ mg/kg dwt. } \\
\hline 1 & 47311 & 5731 & 1203 & 521 & 20.8 & 148 & 9.3 & 0.11 & 1.02 & 1.5 & 2.1 & 1.77 & 0.72 \\
\hline 2 & 26202 & 3620 & 606 & 43 & 5.8 & 69 & 8.7 & 0.10 & 1.33 & 0.6 & 1.2 & 4.29 & 0.74 \\
\hline 3 & 38465 & 4846 & 237 & 83 & 3.5 & 110 & 3.9 & 0.05 & 0.53 & 0.4 & 0.9 & 1.41 & 0.88 \\
\hline 4 & 6929 & 893 & 92 & 68 & 0.3 & 23 & 4.5 & 0.01 & 0.62 & 0.1 & 0.2 & 0.76 & 0.08 \\
\hline 5 & 19790 & 2979 & 167 & 412 & 7.3 & 28 & 8.0 & 0.06 & 2.35 & 0.4 & 0.4 & 1.98 & 0.69 \\
\hline 6 & 11509 & 1351 & 212 & 231 & 1.3 & 51 & 7.4 & 0.08 & 1.01 & 0.2 & 2.6 & 4.95 & 0.23 \\
\hline 7 & 9110 & 1111 & 251 & 209 & 1.0 & 29 & 7.9 & 0.03 & 1.61 & 0.3 & 1.3 & 2.74 & 0.15 \\
\hline 8 & 6360 & 936 & 181 & 213 & 1.0 & 110 & 6.7 & 0.02 & 2.07 & 0.1 & 1.7 & 1.34 & 0.14 \\
\hline 9 & 10807 & 1281 & 150 & 853 & 1.2 & 77 & 8.5 & 0.05 & 1.94 & 0.3 & 0.2 & 1.43 & 0.45 \\
\hline 10 & 40292 & 5030 & 458 & 102 & 0.5 & 57 & 5.9 & 0.03 & 1.37 & 0.7 & 3.3 & 1.18 & 0.16 \\
\hline 11 & 51757 & 6176 & 875 & 415 & 8.7 & 165 & 11.6 & 0.23 & 1.86 & 0.9 & 4.3 & 2.07 & 1.42 \\
\hline 12 & 11362 & 1436 & 295 & 87 & 4.1 & 39 & 6.0 & 0.06 & 0.65 & 0.4 & 0.5 & 2.97 & 0.18 \\
\hline 13 & 7328 & 833 & 86 & 47 & 0.5 & 14 & 2.8 & 0.02 & 0.21 & 0.1 & 0.1 & 0.56 & 0.03 \\
\hline 14 & 6527 & 752 & 57 & 62 & 1.4 & 36 & 1.6 & 0.11 & 0.74 & 0.3 & 0.5 & 0.64 & 1.03 \\
\hline 15 & 48206 & 3821 & 2975 & 384 & 15.4 & 120 & 6,5 & 0,20 & 1,24 & 1,2 & 3,5 & 3,47 & 1,04 \\
\hline $\mathrm{F}$ & 345.7 & 157.9 & 247.6 & 57.6 & 34.8 & 142.3 & 34.1 & 16.8 & 65.9 & 17.4 & 40.2 & 19.6 & 28.2 \\
\hline $\mathrm{F}_{0.05}$ & & & & & & & 1.80 & & & & & & \\
\hline LSD & 4346.4 & 854.4 & 167.5 & 67.8 & 0.8 & 34.7 & 2.4 & 0.06 & 0.4 & 0.3 & 1.1 & 0.6 & 0.3 \\
\hline
\end{tabular}


chemism. According to Helios-Rybicka (1996); Market et al. (1996), and the EMEP Report (2004), the sources of pollution are also, though in a lesser degree, pollutions of trans-boundary type, which modify the real pollution coming from regional and local sources.

The populations of A. platanoides are significantly differentiated in respect of elements' contents in leaves (Table 2).

All the populations occur in the same climatic zone, which, according to Herpin et al. (1996), this enables the comparison of the obtained results. The analysis revealed, that contents of elements in leaves depend on the degree of environmental pollution, i.e. quantitative and qualitative influence of soil and air chemistry. Table 1, which includes the mean values, shows that sites of the highest and higher contents of elements in soil correspond with higher contents of the same elements in leaves of $A$. platanoides (Table 2). The same concerns sites of lowest and low contents of these elements in soil, corresponding with lower contents in A. platanoides leaves. Kabata-Pendias (2001), Walker et al. (2002), Bell and Treshow (2004) mention, that metals' aerosols pollute the soil, and affect the plants. Further, these authors state that the deposit of metals, mainly heavy metals, taken up from soil by plants through their root system and also from leaf surface, is transported to other plant parts. That influence of pollution and the transport of ions is conditioned by various factors, namely by: size and mass of particles, kind of pollution, climatic conditions, wind strength, humidity level, spatial orientation of leaves and their morphological and physiological features (Harrison and Chirgawi 1989; Bache et al. 1991). Therefore, in the present study the chemism of soils and leaves has been analysed, these analyses do not fully reflect the existing here environmental conditions and above all the amount of air deposit.

\section{Cluster, factor and PCA analysis}

of Acer platanoides sites (soils)

The cluster analysis enabled to determine the similarity of A. platanoides sites in respect of chemical components in soil (Fig. 2).
According to Hongjin et al. (1995) this method is proper and is frequently used in geochemical investigations. That method was used in bioindication studies, among others by Kosiba and Kolon (2002), Kosiba (2004) for analyses of pollution of the Lower Silesian territory in respect of dustfall and contents of selected chemical components, mainly heavy metals in plants. The applied method of cluster analysis revealed the similarity of the investigated sites, ordering them into three groups $\mathrm{A}, \mathrm{B}$ and $\mathrm{C}$. The soils of groups $\mathrm{A}$ and $\mathrm{B}$ sites were least similar to sites forming group $\mathrm{C}$. Sites 1 and 2 (A), which occupy an extreme position in the dendrogram included higher contents of chemical elements, in relation to sites 13 and 14 (C) of the lowest contents. Worthy of notice is site 15 (B), which occupies the position on the left of group A. This site, in relation to other sites, is characterized by the highest contents of Fe, $\mathrm{Zn}, \mathrm{Cu}, \mathrm{Co}, \mathrm{Mo}, \mathrm{Cr}, \mathrm{Ni}, \mathrm{Cd}$ and high contents of the remaining elements. The remaining sites of group A show high contents of the analyzed elements. Sites of group C form in the dendrogram a separate group in relation to group A. This dissimilarity of group $\mathrm{C}$ in relation to group $\mathrm{A}$ and $\mathrm{B}$ is conditioned by their lowest and low contents of elements in soil. Taking into consideration the results of cluster analysis, the significance of differentiation between sites and the absolute contents of the analyzed elements in soils of A. platanoides, allow to conclude that sites 4, 9 and $13,14(\mathrm{C})$ are the least contaminated ones. On the contrary, sites 1,2 and 15 of group A are in highest degree subjected to environmental pressure, i.e. to pollution.

By means of factor and PCA analyses obtained was a clear interpretation of interdependences between the variables and structure of the set of observations.

In the factor analysis of variables calculated were the elements of their correlation matrix. Next, on the basis of the slope plot distinguished were two factors, of which the eigenvalue is higher then 1 . The two distinguished factors attain high eigenvalues and reflect together above $90 \%$ of two common variance of the analyzed variables. All factor loadings are characterized by positive values $>0.70$.

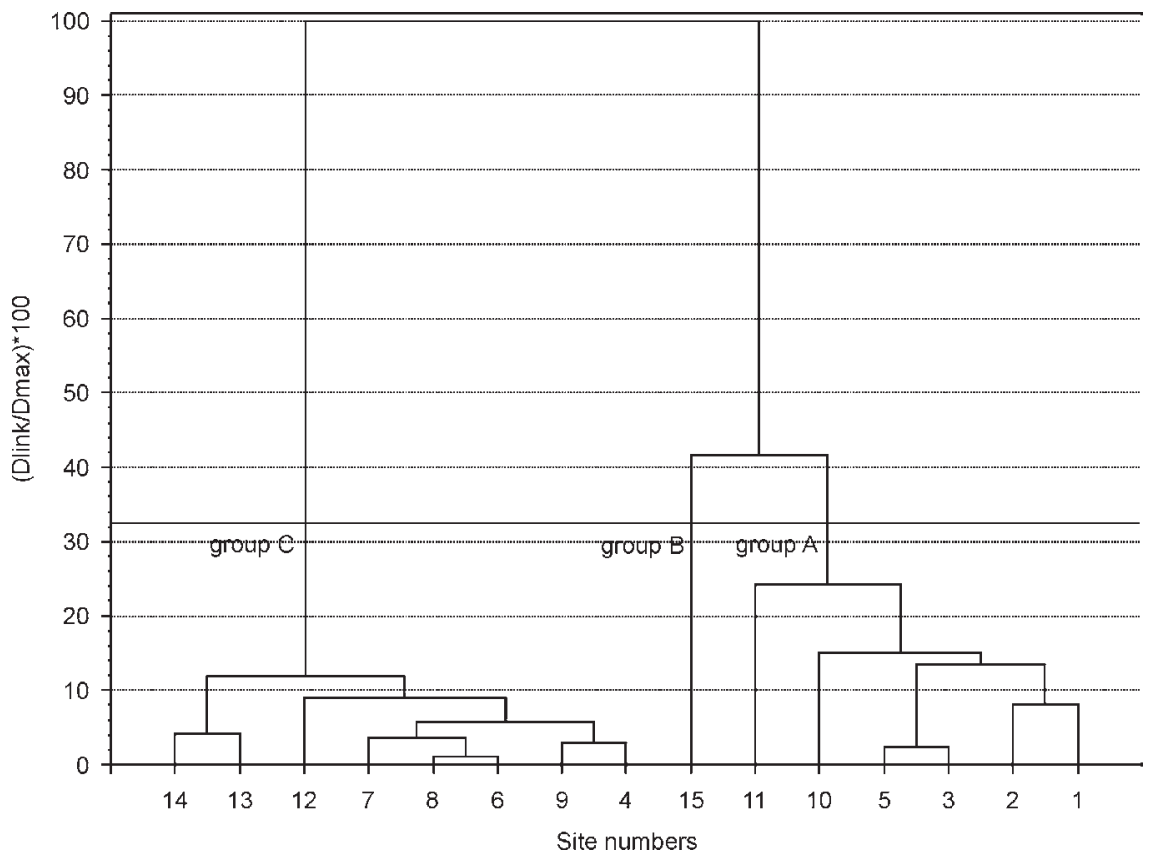

Fig. 2. Hierarchical tree plot of Acer platanoides sites in respect of soil chemical properties. 


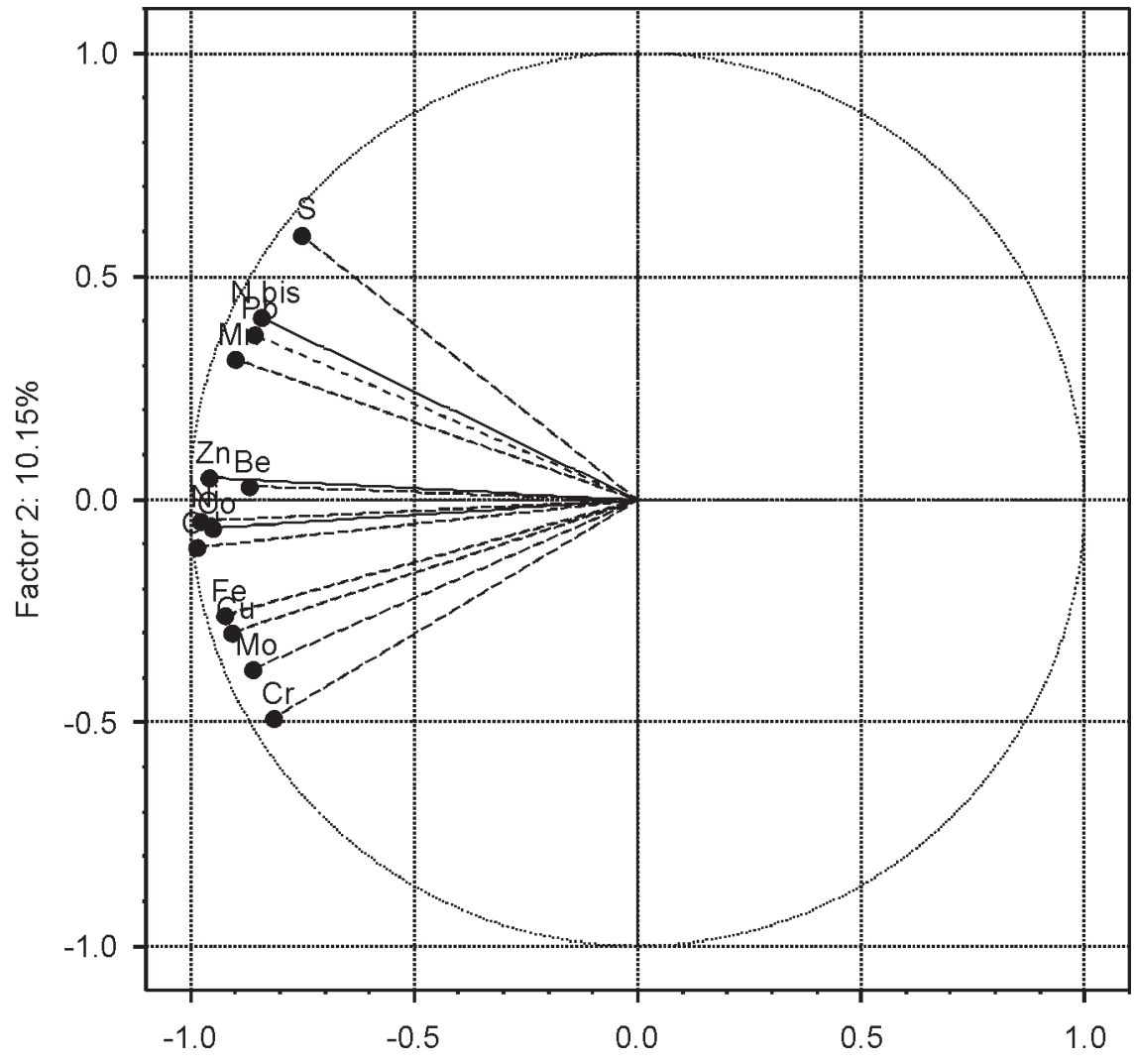

Factor 1: $80.12 \%$
Fig. 3. Projection of soil chemical elements of Acer platanoides sites.
Factor 1, reflecting $80.12 \%$ of common variance, differentiates the sites in respect of $\mathrm{Fe}(0.86), \mathrm{Cu}(0.88)$, Co (0.75), Mo (0.90), Cr (0.93), Ni (0.77), Cd (0.81), whereas factor 2 is responsible for $10.15 \%$ of the reflected variance and concerns $\mathrm{N}$ (0.89), S (0.94), Mn (0.83), Pb (0.84) (Fig. $3)$. On the basis of the obtained results it was recognized that factor 1 represents pollution of industrial character.

Factor 2 concerns pollution coming from urban agglomerations and vehicle transport. According to Kabata (2001), the considerable contents of $\mathrm{Fe}, \mathrm{Cu}, \mathrm{Co}, \mathrm{Mo}, \mathrm{Cr}, \mathrm{Ni}, \mathrm{Cd}$ are caused by the presence of the mentioned elements in industrial dust emissions (site 1, 15), whereas $\mathrm{N}, \mathrm{S}, \mathrm{Mn}, \mathrm{Pb}$ are elements characteristic of pollution of urban agglomerations (site 10,11) and areas with highly intensive vehicle traffic (site 2, 3, 5). Hence, one can conclude that sites of group A are affected by differentiated chemical emissions.

The PCA analysis has been carried out in order to test, whether the reduced set of variables correlated with the two first factors group de facto the analyzed sites. The orientation of sites in relation to the principle components is presented by projection on a plane (Fig. 4).

It was found that the two main components reflect above $90 \%$ of total variability. The first principle component $(80.12 \%)$ characterized by different emission-chemism, above all sites 2, 3, 10, 11, distinctly discriminates being under the influence of urban-agglomeration pollution, versus sites 1 and 15 covered by industrial emissions (coalenergetic industry and non-ferrous metals industry). It also, discriminates sites 5, 12 covered mainly with pollution of vehicle-transport, versus sites $4,6,8,9,13,14$ being beyond the direct influence of pollution. The second principal component $(10.15 \%)$ distinctly differentiates sites $1,2,3$, $10,11,15$ characterized by industrial and urban pollutions of different emission-chemism, versus the remaining sites $4,12,13,14$ of lowest and low impact of pollution, and sites $5,6,7,8,9$ covered mainly by vehicle-transport pollution.

\section{Cluster, factor and PCA analysis of Acer platanoides sites (leaves)}

Like in case of chemical properties in soils, assessed was the similarity of $A$. platanoides populations in respect of contents of the same chemical components in leaves. The dendrogram (Fig. 5) shows the slightest similarity of populations forming group A $(1,3,10,11,15)$, as compared with the remaining populations which form the groups B $(2,5)$ and $C(4,6,7,8,9,12,13,14)$.

Of importance is the ordination of populations belonging to group $\mathrm{B}$ and $\mathrm{C}$. In that case the sites differentiate into two different groups forming populations of their own, and the Ward's method of amalgamation revealed that the two groups are really different. That difference is caused by higher contents of elements in leaves of populations from group B, and the highest contents of elements in populations from group $\mathrm{A}$, while, the populations belonging to group $\mathrm{C}$ show the least and low contents of chemical components.

The comparison of dendrogram structures reveals their similarity (Figs 2 and 5). The same sites (soils) and populations (leaves) form the same groups, except of group B in dendrogram (Fig. 5). Here the dendrogram ordering the populations of group B includes the populations 2 and 5. But, populations 2 and 5 are closer to group A (Fig. 2).

Like in case of chemical soil properties, performed was also the factor analysis for the populations of A. platanoides. On the basis of the slope plot distinguished were two 

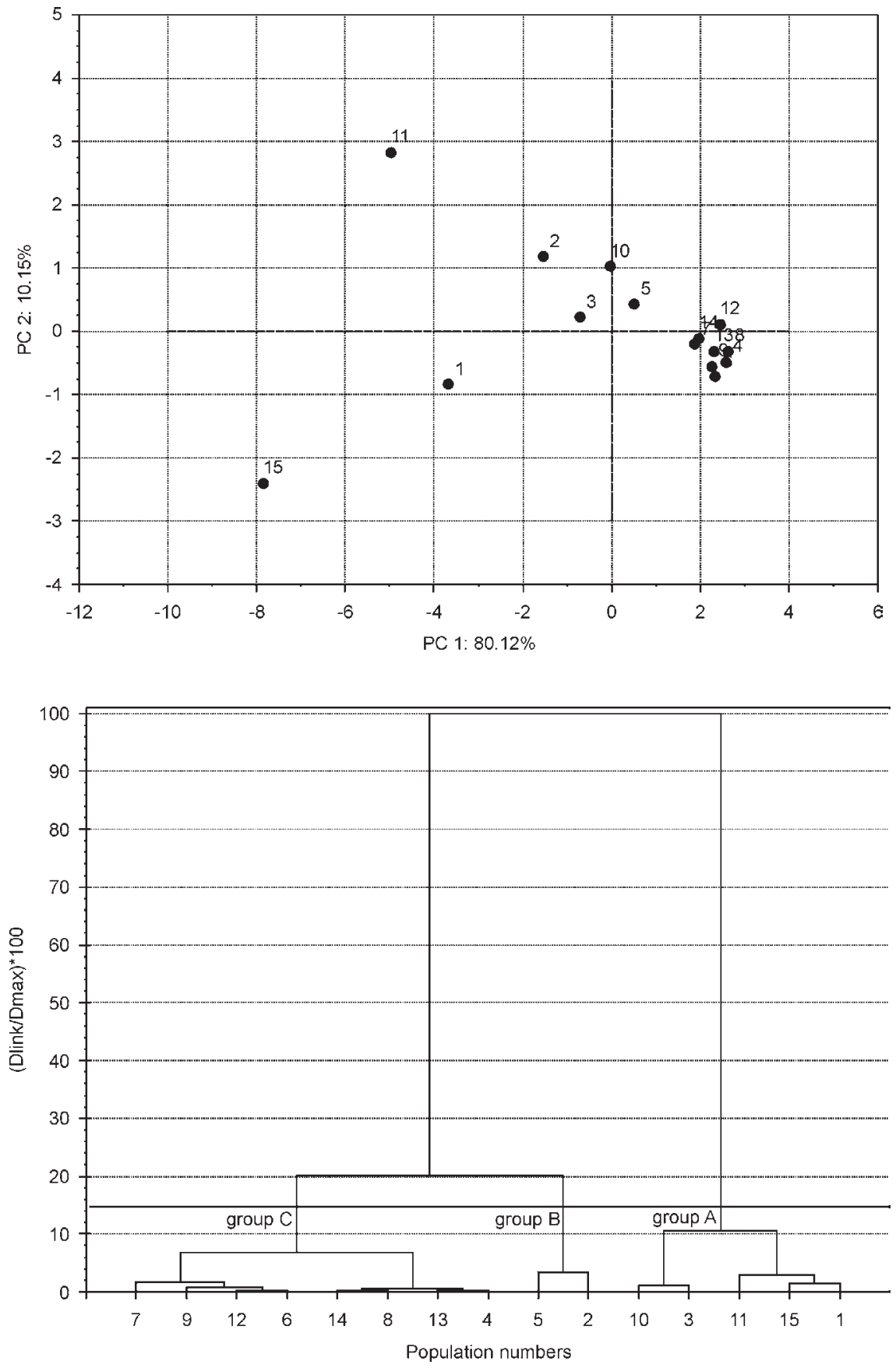

Fig. 4. Ordination of soil samples by the two first axes of PCA analysis, according to the concentration of examined elements.
Fig. 5. Hierarchical tree plot of Acer platanoides populations in respect of leave chemical properties. factors, of which the eigenvalue is higher then 1 . The two factors reflect ca. $70 \%$ of common variance of the analyzed variables. All factor loadings are positive $>0.70$. Factor 1 (53.94\% of common variance) and differentiate of the populations in respect of $\mathrm{N}(0.93), \mathrm{S}(0.84), \mathrm{Fe}(0.80), \mathrm{Pb}$ (0.82), Zn (0.76), Co (0.82), Be (0.93), Cr (0.72), Cd (0.73), whereas factor $2(14.44 \%)$ concerns $\mathrm{Mn}(0.78), \mathrm{Cu}$ (0.86), Mo (0.90) (Fig. 6).

Additionally the PCA has been carried out to test, whether the first two factors de facto are grouping the reduced set of population variables. The orientation of populations in relation to the principal components is presented by projection on the plane (Fig. 7).

The first principal component $(53.94 \%)$ characterizes populations $2,5,6,7,8,9$ being under the impact of vehicletransport, and population 11 influenced by vehicle-transport and urban-agglomeration pollution, versus populations
$1,3,10,15$ influenced by industrial and urban-agglomerations and populations $4,12,13,14,15$ being beyond a direct influence of pollution. The second principal component $(14.44 \%)$ distinctly differentiates populations $1,2,3$, $10,11,15$ polluted by industrial and urban emissions, versus the remaining populations $4,12,13,14$ of lowest and low pollution impact, and populations $5,6,7,8,9$ polluted mainly by vehicle-transport sources.

The compared plots of PCA for sites (Fig. 4) and populations (Fig. 7) of $A$. platanoides indicate that the chemism reflects the pollution of the sites analysed.

\section{Occurrence of Rhytisma acerinium "tar-spots" on Acer platanoides leaves}

The examined populations differ significantly in respect of "tar-spot" numbers (ANOVA, F=88.8, p $<0.05$, $\mathrm{LSD}=10.02)$ (Fig. 8). 

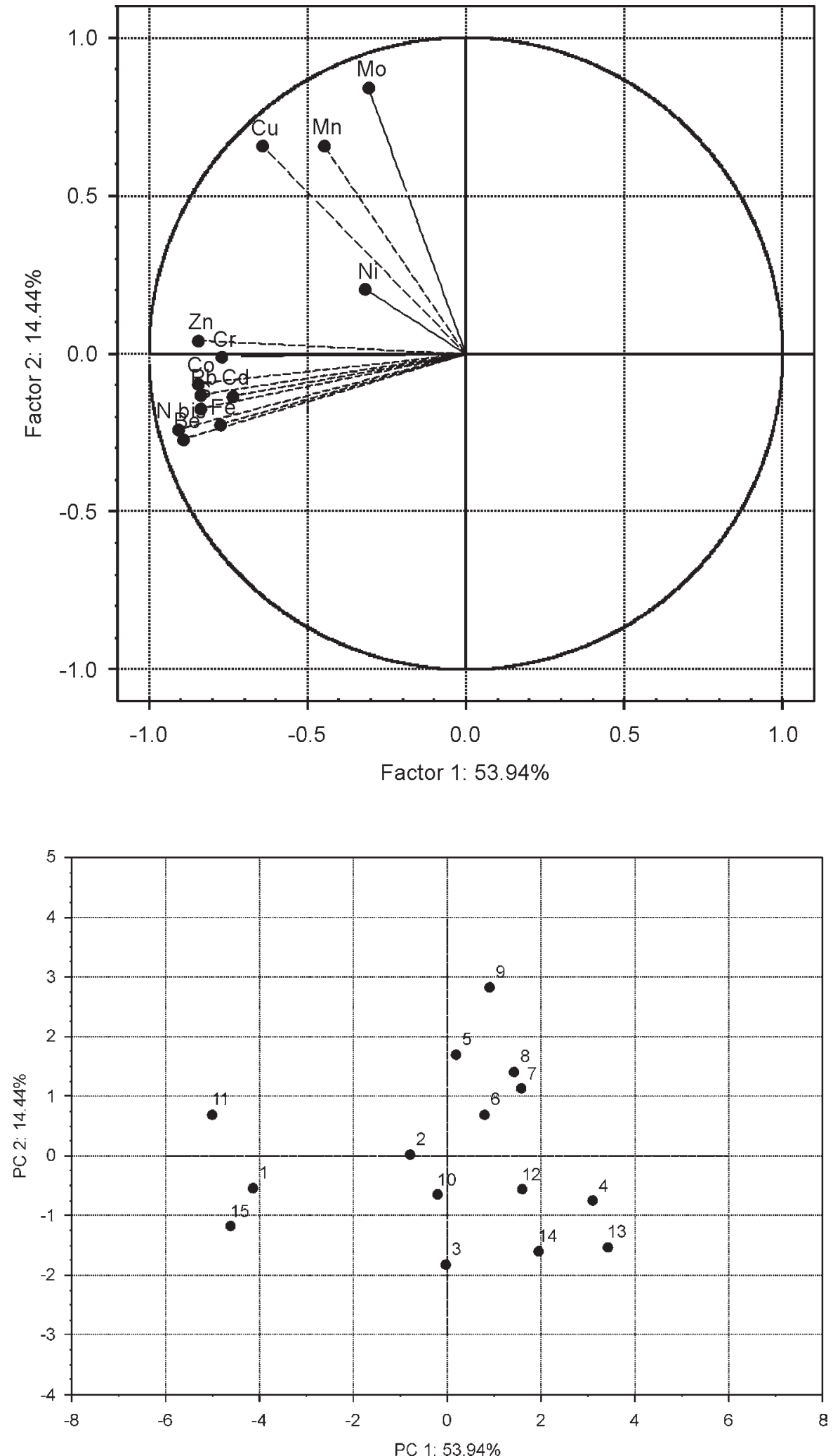

Fig. 6. Projection of leave chemical elements of Acer platanoides sites.
Fig. 7. Ordination of maple leaf samples by the two first axes of PCA analysis, according to the concentration of examined elements.
In populations being within the reach of influence of emission sources of the coal-energetic (site 1), metallurgic industry (site 15), and in areas of urban-agglomerations (sites $2,3,11) R$. acerinium has not been found. Few "tarspots" occur in populations 5, 6, 10 and 12, which are situated closely to thoroughfares and in territories situated beyond direct influence off dust-gaseous pollutions. Numerous and intense infections by the fungus were found in populations $4,7,8,9,13$ and 14 , localized in forest communities far away from traffic, urban and industrial pollution. The differentiated occurrence of "tar-spots" in the analyzed sites, in consideration of the chemical results of soils and leaves show the impact of pollution. No infection of $A$. platanoides by the fungus $R$. acerinium was recorded in sites of the highest and high contents of N, S and heavy metals (group A and B). On the contrary, numerous infections occur on sites of group $\mathrm{C}$ of lowest and lower contents of the analyzed elements, as compared with sites of group 


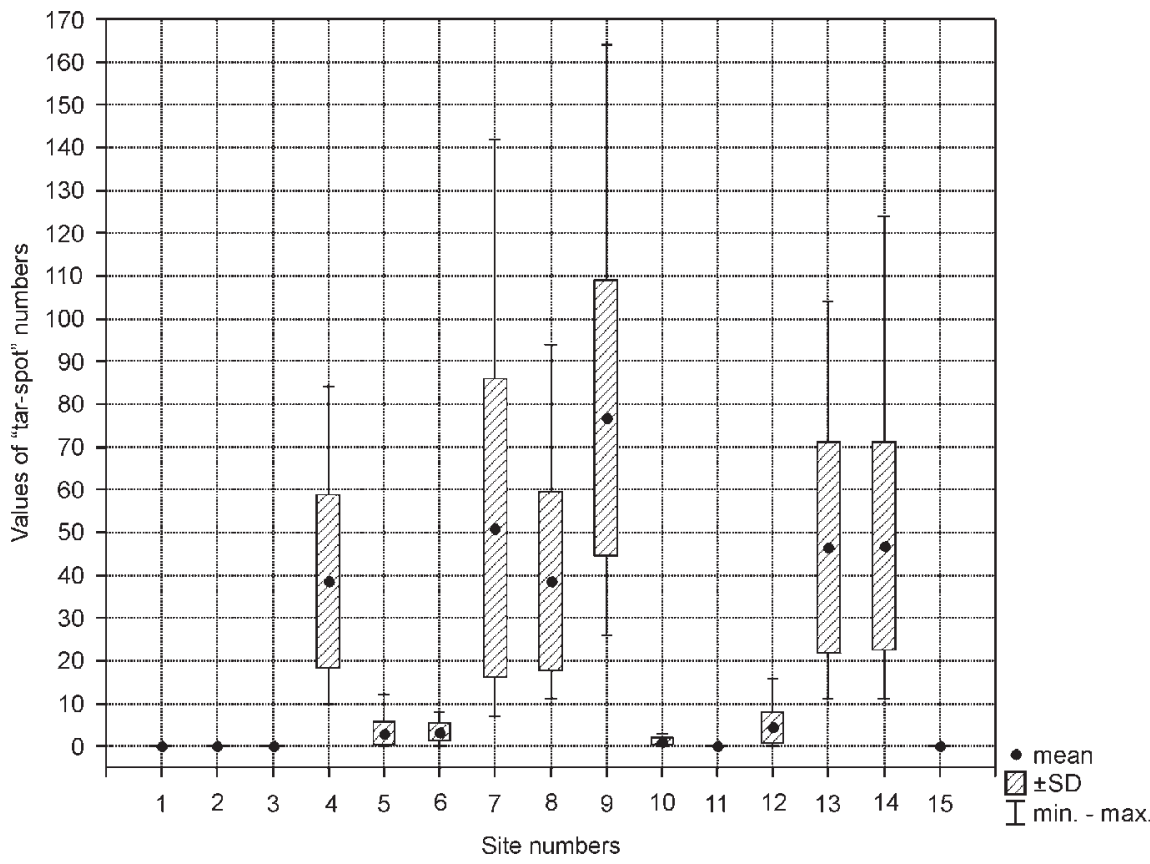

Fig. 8. Basic statistical descriptive values of "tar-spot" numbers on leaves of Acer platanoides.
A sites. An exception make here the sites 5, 6, 10 and 12, of average or low contents of the elements, in which infections of maple-trees occur only sporadically. They are probably contaminated in a small degree. Worthy of notice is the fact, that $A$. platanoides trees growing in decorative double rows or singly show a low number of infections. Here the habitat conditions are different, i.e. high insolation, windy, and of relatively low air humidity as compared with sites occurring in mixed forest communities of wet and shady conditions. $R$. acerinium does not find optimal developmental conditions on sites 5, 6, 10 and 12 . This suggests a significant impact of different habitat conditions upon the small occurrence of $R$. acerinium. The contents of the analyzed chemical components in soil and leaves of A. platanoides sites correspond with that on sites of lowest and low contents of these elements, despite the contents of chemical elements in soils and leaves correspond with that in sites of the lowest and low contents of these elements. On the other hand, an example makes here site 6 , situated ca $600 \mathrm{~m}$ vis-á-vis the cement plant Rozmierka near Strzelce Opolskie, near the road with intense traffic. Here the contents of most of the elements in soil and leaves point to the situation, in which infections should not occur. But they do occur here, though sporadically. It seems that the significant factor is here the influence of limestone dusts from the neighboring plants in Strzelce Opolskie and Opole. Cement and limestone dusts act as a neutralizer in accessibility of sulfur and some heavy metals for plants (Marschner 1995, Siedlecka et al. 2001). This is related with their basic properties through increase of soil reaction and water vapor in air, immobilizing in effect the heavy metals in soil and their assimilability by plants, and thus reducing their toxic activity (Kabata-Pendias 2001) and mechanisms of tolerance to metals (Baranowska-Morek 2003). Sites 7, 8 and 9 are likewise under influence of dusts from those cement sources. Because of the considerable distance of the mentioned sites from the cement sources, the influence of neutralizing dusts on xenobiotics seems to be small. Nevertheless, the infections of $A$. platanoides leaves by the fungus are massive. It is supposed, that this massive occurrence of $R$. aceri- nium, in relation to the remaining sites, is affected by low contents of the elements in soils and leaves, though probably the habitat conditions are also of importance in development of leaf infection. One can suppose, that the variability and differentiation between sites in respect of chemical elements and "tar-spot" numbers on leaves is caused by the level of pollution. The results indicate, that the fundamental factor restricting the occurrence of the infection is the high pollution, mainly of $\mathrm{N}, \mathrm{S}\left(\mathrm{NO}_{\mathrm{X}}, \mathrm{SO}_{\mathrm{X}}\right)$ and heavy metals, but also the proper habitat (microclimatic) conditions for development of that fungus. The results in the present paper are in agreement with investigations of Bevan and Greenhalgh (1976), Vick and Bevan (1976), Greenhalgh and Bevan (1978), Leith and Fowler (1987) in respect of sensitivity of the fungus to $\mathrm{SO}_{2}$ concentrations in the air. Similar relations were also found by Dowding and Richardson (1990), Dowding (1994) and Newsham et al (1995) confirming that the pollution, which takes place in anthropogenic areas (urban, rural, industry), significantly influences the $R$. acerinium occurrence.

The use of biometric traits of ecological objects is an important means for presentation of the environmental status, which in our case are the infection numbers of $R$. acerinium on $A$. platanoides leaves. The usability of various morphometrical techniques in studies of variability of leaves and pollens of trees and shrubs has been also shown by Klein and Paulus (1997), Niinemets and Kull (2003), Tretyakova and Noskova (2004), in relation to environmental pollution.

\section{CONCLUSIONS}

On the basis of all the points discussed above it can be concluded that the Acer platanoides sites are differentiated in relation to the kinds of pollution. The sites are generally polluted by a complex of chemical elements, but in this investigations mainly of industrial origin, which are characterized by higher contents of $\mathrm{Fe}, \mathrm{Cu}, \mathrm{Co}, \mathrm{Mo}, \mathrm{Cr}, \mathrm{Ni}, \mathrm{Cd}$. Pollution from urban-agglomerations and vehicle traffic 
shows higher contents of $\mathrm{N}, \mathrm{S}, \mathrm{Mn}, \mathrm{Pb}$. Both types of air pollution reflect the concentrations of elements accumulated in leaves, including particularly $\mathrm{N}, \mathrm{S}\left(\mathrm{NO}_{\mathrm{X}}, \mathrm{SO}_{\mathrm{X}}\right)$ and $\mathrm{Fe}, \mathrm{Pb}, \mathrm{Zn}, \mathrm{Co}, \mathrm{Be}, \mathrm{Cr}, \mathrm{Cd}$. The occurrence of $R$. acerinium according to the level of pollution results in different numbers of infections on leaves in the particular examined sites. Of significance is the fact that these infections do not occur in heavily polluted sites. In sites of low contents of elements and proper developmental habitat conditions massive infections take place. The study showed that $R$. acerinium is a good tool for assessment of the degree of environmental pollution. However, future investigations ought to take into consideration also the calibration of the response of the fungus along the pollution gradient, the effect of other pollutants and microclimate conditions before using it for bio-monitoring. The applied cluster, factor and PCA analyses are useful numerical techniques for ordination of results, and ought to be taken into account as a possible tool of estimation of various plants and their biotopes.

\section{LITERATURE CITED}

BACHE C.A., GUTENMANN W.H., RUTZKE M., CHU G., ELFVING D.C., LISK D.J. 1991. Concentrations of metals in grasses in the vicinity of a municipal refuse incinerator. Arch. Environ. Contam. Toxicol., 20, 4: 538-542.

BAKER A.J.M. 1981. Accumulators and excluders-strategies In the response to plants of heavy metals. J. Plant Nutr., 3: 643-646.

BAKER A.J.M., MCGRATH S.P., REEVES R.D., SMITH J.A.C. 2000. Metal hyperaccumulator plants: a review of the ecology and physiology of a biological resource for phytoremediation of metal polluted-soils. In: Terry N., Banuelos G. (eds), Phytoremediation fo contaminated soil and water. Lewis Publishers, London, pp. 85-107.

BARANOWSKA-MOREK A. 2003. Roślinne mechanizmy tolerancji na toksyczne działanie metali ciężkich. Kosmos, 52, 2-3: 283-298 (in Polish with English summary).

BELL J.N.B., TRESHOW M. 2004. Zanieczyszczenie powietrza a życie roślin. Wyd. Nauk.-Tech., Warszawa (in Polish).

BEVAN R.J., GREENHALGH G.N. 1976. Rhytisma acerinum as a biological indicator of pollution. Environ. Pollut., 10, 271-285.

BROWER J.E., ZAR J.H., VON ENDE C.N. 1998. Field and laboratory methods for general ecology. WCB/McGraw-Hill, Boston, Massechusetts Burr Ridge, Illinois Dubuque, Iowa Madison, Wisconsin New York, San Francisco, California St. Louis, Missouri.

BURTON M.A.S. 1986 Biological monitoring of environmental contaminants (plants). MARC Report Number 32. Monitoring and Assessment Research Centre, King's College London, University of London.

CHENG-LIN H., PIEPENBRING M. 2005. Known and two new species of Rhytizma (Rytismales, Ascomycota) from China. Mycopathologia, 159: 299-306.

CONTI M.E., IACOBUCCI M., CECCHETTI G. 2005. A statistical approach applied to trace metal data from biomonitoring studies. Int. J. Environ. Pollut., 23, 1: 29-41.

CORBIN J.D., AVIS P.G., WILBUR R.B., 2003. The role of phosphorus availability in the response of soil nitrogen cycling, understory vegetation and arbuscular mycorrhizal inoculum potential to elevated nitrogen inputs. Water, Air, Soil Pollut., 147: 141-161.

CORNELISSEN J.H.C., PEREZ-HARGUINDEGUY N., GWYNN-JONES D., DIAZ S., CALLAGHAN T.V., AERTS R. 2000. Autumn leaf colours as indicators of decomposition rate in sycamore (Acer pseudoplatanus L.). Plant Soil, 225: 33-38.
DOWDING P. 1994. Leafyeast survey for air pollution monitoring. In: Biological monitoring of the environment by Salank, J., Jeffre, D. and Hughe, G.M. (eds), IUBS Methodology series, CAB International, Oxon, UK.

DOWDING P., RICHARDSON D.H.S. 1990. Leafyeasts as indicators of air quality in Europe. Environ. Pollut., 66, 3: 223-235.

DURAVETZ J.S., MORGAN-JONES J.F. 1971. Ascocarp development in Rhytisma acerinum and R. punctatum. Can. J. Bot., 49: 1267-1272.

EMEP Status Report. 2004. Heavy metals: transboundary pollution of the environment, Status Report 2/2004. MCS-E \& CCC.

FARR D.F., BILLS G.F., CHAMURIS G.P., ROSSMAN A.Y. 1989. Fungi on Plants and Plant Products in the United States. APS Press, St. Paul, USA.

FELLNER R. 1989. Mycorrhiza-forming fungi as bioindicators of air pollution. Agric. Ecosystems Environ., 28, 1-4: 115.

FELLNER R., PEŠKOVÁ V. 1995 Effects of industrial pollutants on ectomycorrhizal relationships in temperate forests. Can. J. Bot., 73, Suppl. 1: 1310-1315.

FENN M.E., DUNN P.H., DURALL D.M. 1989. Effects of ozone and sulfur dioxide on phyllosphere fungi from three tree species. Appl. Environ. Microbiol., 55, 2: 412-418.

GREENHALGH G.N., BEVAN R.J. 1978. Response of Rhytisma acerinum to air pollution. Trans. Br. Mycological. Soc., 71, 491-523.

HARRISON R.M., CHIRGAWI M.B. 1989. The assessment of air and soil as contributors of some trace metals to vegetable plants. I. Use of a filtered air growth cabinet. Sci. Total Environ., 83, 1-2: 13-34.

HAWKSWORTH D.L., KIRK P.M., SUTTON B.C., PEGLER D.N. 1995. Ainsworth and Bisby's Dictionary of the Fungi, 8th ed. CABI Publishing, CAB International, Wallingford, UK.

HELIOS-RYBICKA E. 1996. Impact o mining and metallurgical industries on the environment in Poland. Pergamon, 11: 3-9.

HERPIN U., BERLEKAMP J., MARKERT B., WOLTERBEEK B., GRODZIŃSKA K., SIEWERS U., LIETH H., WECKERT V. 1996. The distribution of heavy metals in a transect of the three states the Netherlands, Germany and Poland, determined with the aid of moss monitoring. Sci. Total Environ., 187: 185-198.

HONGJIN J., YONGHZENG Z., XISHENG W. 1995.Correspondence cluster analysis and its application in exploration geochemistry. J. Geochemical Explor., 55: 137-144.

HUTCHINSON T.C., SAGER E. 2000. The possible relationship between litter decomposition rate and metal accumulation in the forest floor of maple woods along urban-rural corridor from Toronto, Ontario. In: Nriagu J. (ed.) 11th Annual International Conference on Heavy Metals in the Environment. Ann Arbor. Michigan: University of Michigan, School of Public Health, USA.

JONES S.G. 1925. Life history and cytology of Rhytisma acerinum (Pers.) Fries. An. Bot., 39: 41-75.

KABATA-PENDIAS A. 2001. Trace Elements in Solis and Plants. CRC, Press, Boca Raton.

KIRK P.M., CANNON P.F., DAVID J.C., STALPERS J.A. 2001. Ainsworth and Bisby's Dictionary of the Fungi, 9th ed. CABI Publishing, CAB International, Wallingford, UK.

KLEIN R., PAULUS M. 1997. Biometric sample characterization. Part II. The relation between size of needles and concentrations of airborn pollutants. Chemosphere, 34, 9/10: 2015$-2021$.

KOSIBA P. 2004. Biomonitoring of air and reactions of mosses in conditions of pollution with industry emissions. Acta Univ. Wratislaviensis, No 2714, Prace Bot., 80, pp. 109.

KOSIBA P., KOLON K. 2002. Disturbances of ionic equilibrium in mosses of contaminated areas. Acta Soc. Bot. Pol., 71, 4: 323-328.

LEGENDRE P., LEGENDRE L. 1998. Numerical ecology. 2nd English edition. Elsevier Science BV, Amsterdam. 
LEITH I.D., FOWLER D. 1987. Urban distribution of Rhytisma acerinum (Pers.) Fries (tar spot) on sycamore. New Phytol., 108, 2: 175-181.

LORENZINI G., FARINA R., GUIDI L. 1990 The effects of sulphur dioxide on the parasitism of the rust fungus Uromyces viciae-fabae on Vicia faba. Environ. Pollut., 68, 1: 1-2.

MADEJÓN P., MARANON T., MURILLO J.M., ROBINSON B., 2005. White poplar (Populus alba) as a biomonitor of trace elements in contaminated riparian forest. Environ. Pollut., 132: $145-155$.

MARKERT B.A., BREURE A.M., ZECHMEISTER H.G. 2003. Definitions, strategies and principles for bioindication/biomonitoring of the environment. In: Markert B.A., Breure A.M., Zechmeister H.G. (eds). Bioindicators and biomonitors. Elsevier, Oxford, p. 3-39.

MARSCHNER H. 1995. Mineral nutrition of higher plants. Academic Press. Harcourt Brace \& Company, Publishers, London, San-Diego, New York, Boston, Sydney, Tokyo, Toronto.

MARX D.H., SHAFER S.R. 1989 Fungal and bacterial symbioses as potential biological markers of effects of atmospheric deposition on forest health. In: Biologic markers of air pollution stress and damage in forests, Committee on biological markers of air pollution damage in trees, National Research Council, National Academy Press, Washington D.C.

NEWSHAM K.K., INESON P., FRANKLAND J.C. 1995. The effects of open-air fumigation with sulphur dioxide on the decomposition of sycamore (Acer pseudoplatanus L.) leaf litters from polluted and unpolluted woodlands. Plant, Cell Environ., 18, pp. 309.

NIINEMETS U., KULL K. 2003. Lear structure vs. nutrient relationships vary with soli condition in temperate shrubs and trees. Acta Oecolog., 24: 209-219.

NORDÉN B., APPELQVIST T. 2001. Conceptual problems of ecological continuity and its bioindicators. Biodiversity Conserv., 10: 779-791.

POIKOLAINEN J. 2004. Mosses, epiphytic lichens and tree barks as biomonitors for air pollutants - specifically for heavy metals in regional surveys. Oulu University Press, Oulu, Finland.

SALEMAA M., DEROM J., HELMISAARI H.S., NIEMINEN T., VANHA-MAJAMAA I. 2004. Element accumulation in boreal bryophytes, lichenes and vascular plants exposed to heavy metal and sulfur deposition in Finland. Sci. Total. Environ., 324: 141-160.

SAWICKA-KAPUSTA K., ZAKRZEWSKA M., BAJOREK K., GDULA-ARGASIŃSKA J. 2003. Input of heavy metals to the forest floor as a result of Cracow urban pollution. Environ. Intern., 28, 691-698.

SCHAFFERS A.P., TERMORSHUIZEN A.J. 1989. A field survey on the relations between air pollution, stand vitality and the occurrence of fruitbodies of mycorrhizal fungi in plots of Pinus sylvestris. Agric. Ecosystems Environ., 28: 449-454.

SIEDLECKA A., TUKENDORF A., SKÓRZYŃSKA-POLIT E. MAKSYMIEC W., WÓJCIK M., BASZYŃSKI T., KRUPA Z. 2001. Angiosperms. In: Metals in the environment. Analysis by biodiversity. Prasad M.N.V. (ed.) Marcel Dekker, Inc., New York, Hyderabad, India, pp. 171-217.

SINGH A.K., BHARAT R. 1990. Effect of $\mathrm{SO}_{2}$ and $\mathrm{NH}_{3}$ on growth behavior of some phylloplane fungi of wheat in vitro. Water, Air Soil Pollut., 49, 3-4: 343.

SIWICKI A.K. (ed.). 1999. Biologiczne monitorowanie skażenia środowiska. Wpływ ksenobiotyków na organizm zwierząt i człowieka. Wyd. IRS. Olsztyn (in Polish).

SOKAL R.R., ROHLF F.J. 2003. Biometry. The principles and practice if statistics in biological research. W.H. Freeman And Company, New York.

STATSOFT, INC. 2005. STATISTICA (data analysis software system), version 7.1, StatSoft, Inc., Tulsa, OK, USA, (www.statsoft.com).

SUTTON B.C. 1980. The Coelomycetes. Fungi imperfecti with pycnidia, acervuli and stromata. Commonwealth Mycological Institute, Kew.

SZABÓ I. 2003. Leaf pathogenic fungi of forest tress and shrubs in Hungaria. Fritschiana, 42: 67-70.

TIEDEMANN A.V., WEIGEL H.J., JAGER H.J. 1991. Effects of open-top chamber fumigations with ozone on three fungal leaf diseases of wheat and the mycoflora of the phyllosphere. Environ. Pollut., 72, 3, 205.

TRETYAKOVA I.N., NOSKOVA N.E. 2004. Scotsh pine pollen under condition of environmental stress. Russ. J. Ecol., 35, 1: 20-26.

VICK C.M., BEVAN R. 1976. Lichens and tar spot fungus (Rhytisma acerinum) as indicators of sulphur dioxide pollution on Merseyside. Environ. Pollut., 11: 203-216.

WALKER C.H., HOPKIN S.P., SIBLY R.M., PEAKALL D.B. 2002. Podstawy ekotoksykologii. PWN, Warszawa (in Polish).

WEBER R.W.S., WEBSTER J. 2002. Teaching techniques for mycology: 18. Rhytisma acerinum, cause of tar-spot disease of sycamore leaves. Mycologist, 16: 120-123. 